\title{
Erratum to: The contribution of the digital elevation models and geographic information systems in a watershed hydrologic research
}

\author{
A. Mendas $\cdot$ H. Brek $\cdot$ B. Lakache
}

Published online: 30 March 2010

(C) The Author(s) 2010. This article is published with open access at Springerlink.com

Erratum to: Applied Geomatics

DOI 10.1007/s12518-010-0017-x

Owing to an unfortunate misunderstanding during the proof correction process, the names of two authors were omitted.

The full list of authors (with affiliations) should read:

A. Mendas ( $₫)$, H. Brek, B. Lakache

National Center of Spatial Techniques,

Arzew, POB 13, 31200 Oran, Algeria

e-mail: mendask@yahoo.fr

Open Access This article is distributed under the terms of the Creative Commons Attribution Noncommercial License which permits any noncommercial use, distribution, and reproduction in any medium, provided the original author(s) and source are credited.

The online version of the original article can be found at http://dx.doi. org/10.1007/s12518-010-0017-x.

A. Mendas $(\bowtie) \cdot$ H. Brek $\cdot$ B. Lakache

National Center of Spatial Techniques,

Arzew, POB 13, 31200 Oran, Algeria

e-mail: mendask@yahoo.fr 